\title{
ON THE NATURE OF THE BEAST: RE-CHARTING POLITICAL GEOGRAPHIES OF THE EUROPEAN UNION
}

\author{
by \\ James D. Sidaway
}

Sidaway, J.D., 2006: On the nature of the beast: Re-charting political geographies of the European Union. Geogr. Ann., 88 B (1): $1-14$.

\begin{abstract}
This review paper begins with the premise that since the European Union remains a process of construction with no agreed or pre-designated end-point, its power structure is open to a diverse range of interpretations. Moreover, the apparent novelty of the EU renders it hard to characterize according to familiar taxonomies. The novelty lies in part in the complex territorial configurations of authority in the EU. Different conceptualizations of the EU are varied readings of the structure, balance and scales of authority - which thereby invoke different actions and spaces of possibility.
\end{abstract}

Key words: European Union, multi-level governance, networks, regions, territoriality, scale, geopolitics.

\section{Introduction}

Paradoxical as it may seem, the emergence over the last few years of a process of political unification in Europe and the debate over the best forms of 'integration' appear to have heightened the uncertainty about the nature of the European territory. To the point that it can be maintained that Europe is anything but a territory. This uncertainty results above all from an excess of possible European territories in the future; or better, from an excess of geopolitical scenarios, each of which attempts to project its peculiar character on European space.

(Boeri, 2001, p. 357)

This paper explores literatures on the shifting political geographies of the European Union. Although the enlargement of the EU from fifteen to twenty-five members alters many of these (Agnew, 2001; Kuus, 2004; Moisio, 2002; Smith, 2002) and underpins ongoing debates about the proposed EU constitution, neither enlargement nor the constitutional proposal provides the focus here. Instead, the focus of the paper is the chal- lenges that the EU poses for conventional understandings of the ensemble of relations between territory-government-power that have traditionally lain at the heart of political geography. Even so, the range of potentially relevant material is vast. What follows is inevitably a highly selective and partial review, focused on English-language literatures. The aim however is to outline the main currents of debate and analysis.

The EU lends itself to a wide diversity of interpretations about its modus operandi, structure and relationships to sovereignty and territory. Thus, as Church and Phinnemore (2002, p. 2) note:

the EU is an unusual construction. It is not a single body but...one resting on several 'pillars'....Hence, it is partly 'supra-national' in that its collective decisions have authority within the member states. At the same time it is 'intergovernmental' in that it is based on, and structured through, specific strategic agreements among the member states.

Early on, the paper notes the apparent strangeness of some of the interpretations of the EU that are in circulation (for example, fundamentalist Protestant readings of the EU based on biblical prophecy). While far from most mainstream views and social science analyses, such readings do serve to illustrate the ways that the EU lends itself to creative interpretation. With the range of these in mind, the bulk of the paper reviews and explores the consequences of a range of theorizations of the political geography of the EU and, insofar as they also inform these political geographies, it necessarily also ventures into the economic ${ }^{1}$, social-cultural ${ }^{2}$ and $u_{\text {urban }}^{3}$ geographies of the Union.

However, a focus on the political geography of European integration offers insights into the European polity, since the complex territorial configurations and scaled narratives of authority constitut- 
ing the EU are arguably significant parts of what renders it distinctive. The next section reiterates the ways that the apparent novelty (and complexity) of the EU enables a diversity of interpretations of its political character and dominant scales of action. I go on to explore the insights and consequences of different readings of the EU, beginning with those that concentrate on the actions and scale of 'national' member states. Following this, I examine other scales of reference, considering, in turn, (both substate and macro) regions, networks and the interactions of multiple levels. It notes both how regions - including city regions and urban networks - have been the most durable alternative reference points, although diversity of regional modes of governance defies easy summary. The conclusions return to what is at stake in distinguishing between different interpretations.

My overall task is enabled by prior critical exploration of EU/European territoriality, such as the review by Paasi (2001), Hellström's (2003) account of border-making processes in European integration and the suggestive analysis by Anderson (1996) on which - to adapt some of the metaphors characteristic of European integration (see Clark, 2001; Shore, 1997) - this paper 'builds', 'enlarges' and 'deepens'. Prior collections and texts on the European Union's geographies provide useful points of departure (e.g. Blacksell, 1977; Graham, 1998; Heffernan, 1998; Hudson and Williams, 1999; Jönsson, Tägil and Törnqvist, 2000; Lee and Ogden, 1976, McNeill, 2004; Parker, 1983). However, over the past couple of decades, the range ${ }^{4}$ and richness of wider scholarship on the EU has grown greatly. Inevitably I cannot be comprehensive and the focus here is on English-language texts. What follows therefore makes forays into a vast multiand interdisciplinary literature and teases out some key aspects of the political geographies of European integration.

\section{An unknown beast?}

Writing about Russian ${ }^{5}$ relationships with the European Union, The Economist (2005, p. 48) magazine recently noted that, unlike the Baltic states (which are already members) and Ukraine (whose leadership now speaks openly and often about its ambitions to join the EU):

A country with recent memories of being one of the world's two superpowers cannot contemplate the relatively humbling idea of being just another member of the European club. The Brussels ideology, with its emphasis on 'shared sovereignty' and the dismantling of borders, is unappealing to a Russian leadership that is more comfortable with traditional ideas of power and territory.

The Economist goes on to note how (and here it citing an article in the influential Moscow-based Russia in World Affairs magazine) key Russian commentators have: 'concluded that 'the European Union is just a new kind of empire': one that threatens to continue to expand into Russia's historic sphere of influence'.

As is detailed below, these Russian critics are not the only source of designations of the EU as an empire. However, the apparent novelty of the EU's process and structures, and the open-ended Europe on the move (enlargement, fast-tracks, accessions and blockages to the east), renders it hard to characterize according to familiar taxonomies. Europeanization is also 'a fashionable but contested concept' (Olsen, 2002). Most analyses agree that the EU is not a state (even allowing for the variety among them). Yet nor can the EU be credibly designated merely as a traditional intergovernmental or international organization. Others point out that it can never be a state, since these are conventionally understood - despite some 'state-like characteristics' (e.g. flag and anthem, economic and monetary union, and moves to a common defence and citizenship provisions in recent European treaties). Thus, in Helen Wallace's (2000, p. 66) terms, the EU 'is not a state and there are few areas of policy in which it is the exclusive location for generating collective action or solving policy dilemmas'. Furthermore, as Nugent and Paterson (2003, p. 103) remind us:

The citizenship provisions in the Maastricht and Amsterdam Treaties are extremely modest and complement rather than threaten statebased citizenship provisions. Similarly, the defence conclusions of the Nice Treaty fall a very long way short of a European army, with it as yet being unforeseeable that the European Union could enjoy the monopoly of physical coercion which has long been seen to be a defining feature of states. As for EMU it is often forgotten that the Irish Republic had a long standing currency union with the United Kingdom and that Benelux was also a currency union. 
Beyond mere wariness, however, of the EU as a proto-state (something that has been evident in many political debates and polemics), the European Institute of Protestant Studies in Belfast, directed by Ian Paisley, Leader of the Ulster Democratic Unionist Party (DUP), interprets the EU as a conspiracy directed by the Vatican. Invoking the authority of biblical prophecy they characterize the EU as a plot by the papacy:

aimed at reclaiming all those regions of Europe which were wrested from Rome through the Great Schism of the eleventh century, the Protestant Reformation of the sixteenth, and, more recently, the communisation [sic] of Eastern Europe....Thus Romanism can again be seen rearing its ugly head as the one constant force that has bedeviled all European history and politics and conducted a vicious campaign against Protestant Britain for centuries.

(Noble, 1998, p. 9)

While certain aspects of the Vatican's role, for example, in Poland and Croatia, are widely acknowledged features of European 'geopolitics', and although it shares common ground with wider British 'euroscepticism', the vision of the European Institute of Protestant Studies appears to belong more to the domain of conspiracy theories: the worlds of alien abductions, The $X$-Files and, more sinisterly, The Protocols of the Elders of Zion. Yet Shirlow's (2000) research on fundamentalist Protestant politics in Northern Ireland indicates that variants on this position circulate widely in the charged and uncertain context of Ulster. Such conspiracy theories are perhaps all too easy to dismiss on the part of secular-minded social scientists. For as Mitchell (1998, p. 89) points out:

Scholars associated with the Fundamentalism Project (American Academy of Arts and Sciences) have recently focused on how small groups of true believers in different nations and historical epochs manage to captivate large parts of the body politic....It turns out that in almost every known movement we can find leaders formulating dramatic eschatologies of an impending cosmic upheaval - even in cultures that have no prior tradition of sacred apocalyptic texts.

Noting that visions of the EU as the 'Antichrist' also circulate in some popular African religious texts/tracts, Ellis and ter Haar (1998, p. 179) comment that:

Their meaning is to be sought less in a refined deconstruction of their symbolism, although the symbols used are indeed informative, than in considering how entire cultures come to consider reality in specific ways, including in terms of interaction between the visible and invisible forces, which they believe to constitute the world and to determine its evolution.

Moreover, 'softer' variants of the 'Vatican conspiracy' version of the EU have been more widely active. Sassoon's (1997, p. 176) account of the West European Left in the twentieth century notes that in the UK after 1945:

The twin pillars of Labour [government and party] foreign policy were anti-Europeanism and pro-Americanism. The first was exemplified by Labour's scorn for the Schuman Plan (which would lead to the setting up of the European Coal and Steel Community, the first major step towards the EEC), condemned by the 'intellectual' organ of the Left, the New Statesman, as a conspiracy headed by French and German industrialists and the Pope.

Moreover, conspiracy theories building on Christian eschatology purporting to expose the EU circulate in 'popular geopolitics' in the USA and, albeit to a lesser extent, among many fundamentalist Christians elsewhere. A few moments on the internet searching with terms such as Bible prophecy, revived Roman Empire, New World Order and European Union will yield dozens of accounts. More widely, Herman (2000, p. 23) notes that those conservative American Protestants who believe in the literal truth of the bible and read it in prophetic tone:

have long been fascinated by Europe. Theologically, premillennial belief is based primarily upon interpretations of the Revelation of John - the last book of the New Testament.... The Revelation is seen to mandate that the Roman Empire will revive, that it will likely be led by the Antichrist, and that this new Empire, and its leader, will meet their ends in Israel at the hands of the returning Christ and his saints.

The EU is read among such believers as the New Rome in the process of becoming. Exploring how 
and why they envision Europe in such ways, Herman acknowledges that the topic may seem obscure or trivial. However, he cautions that it is neither. He notes that over $60 \%$ of Americans are in no doubt that Christ will return, and prophecy belief permeates strands of popular culture and animates the religious Right (see also Bower, 1992). The 'Beast' and the 'Antichrist' of Revelations are blended with Old Testament prophecy to populate a fantastic geopolitics of fears and expectations:

Conservative premillennial eschatology informs many of the political positions adopted by the Christian Right (CR) in the United States. For example, the CR's enthusiastic support for Israel...particularly in light of its continued anti-Semitism, makes little sense without an understanding of the role Jewish people must play at the world's end.... Similarly, the CR's pro-defence and patriotic stance is, for many, linked to the pre-ordained role the United States is destined to play in the final days....Understandings about Europe... are also importantly shaped by endtimes belief....During the twentieth century, from the first stirrings of European integration, conservative Protestant prophesiers in the United States became both intrigued and horrified with European developments. European union both seemed to fulfil prophecy, creating the potential for the 'ten nation confederacy', [predicted, it is said, in Revelations] and played on old, evocative, and, in many respects, anti-Catholic beliefs about Roman power.

(Herman, p. 28 and 30, 2000)

Herman goes on to chart the debates among the millenarians about the centralization of power in the $\mathrm{EU}$, the number of members and their (pre)designated roles in 'God's plan'.

While such religious analyses proliferate and circulate in popular culture, and narratives about the EU circulate widely in diverse political contexts (Nicolaïdis and Howse, 2002), accounting for and analysing the nature of the EU has also long posed challenges to social sciences. While not quite The Beast of millenarian prophecy, when it comes to theorizing the EU, there is nevertheless a widespread sense that we are dealing with something challenging and new that requires fresh interpretations. And there are no shortages of these. Thus one recent book-length survey of Theories of European
Integration noted: 'the sheer range and vibrancy of theoretically informed work touching upon the European Union and European integration, much of which has appeared during the time of writing' (Rosamond, 2000, p. xi).

However, another text on Theorizing European Integration comments that: 'Having welcomed the new millennium, and after nearly five decades of uninterrupted theorizing about European integration, international scholarship is still puzzled as to what exactly the EU is or may come to resemble in the future' (Chryssochoou, 2001, p.1).

The subsequent sections of this paper therefore continue to investigate 'the nature of the (EU) beast'. Although Bornschier (2001,p. 187) recently called the EU ' a somewhat strange hermaphrodite - something between a confederation of states and a federal state', metaphors of the Union as an 'unknown animal' have been around for over thirty years. Puchala (1972) thus described efforts at theorization of European integration and the emergent European polity via the parable of the blind men and the elephant. None of the blind men know quite what kind of creature it is they are touching, but those who feel the trunk will describe a very different beast to those who touch other parts of its anatomy. More recently, Chryssochoou (2001, p. 15) has revisited this confusing comparative zoology:

The 'elephant', however, to recall Puchala's colourful metaphor, is not easy to manipulate in theoretical terms: it often turns into a "chameleon' adjusting itself to the actual requirements of the day. In other words, it may not only be the case that various integration theorists are aware of a rather limited picture of a barely describable and, hence, conceptually evasive political animal, but also that the creature itself may indeed change so rapidly as to render the whole process of its study (including both sector-specific analyses and systemwide theorizing) an exercise that is ultimately misleading.

While none of these things are entirely new or confined to contemporary Europe, Chryssochoou usefully marks how continuing uncertainty as to how to categorize and characterize European integration derives, in part, from the particular and novel complex territorial configuration of authority that is the Union. This is not a classic state, even if it has features in common with federal state structures. Moreover, different conceptualizations of the EU 
are, in part, different readings of the structure and balance of scales of authority. This is not to say that ideas focused on the roles of European states do not remain influential. In such literatures, classical notions of the primacy of the sovereign nation-state and the balance of power are presented as underpinning the dynamics of the EU and its institutions. In the academic literature about European integration, early theoretical statements of this position (Hoffmann, 1966) have been elaborated in recent years (Moravcsik, 1991, 1993, 1998) and also revisited by historians of European integration (Milward, 1992, 1993; Milward et al. 1993). In Milward and Sørensen's (1993, p. 21) words:

our argument runs like this. Nation-states have a certain portfolio of policy objectives which they will try to realize in the face of economic and political internationalization. These policy objectives are almost entirely shaped by domestic political pressures and economic resources and will therefore vary from country to country over time. In order to advance these objectives nation-states will attempt to use what international framework there is at hand. Many of these objectives can and will be pursued by expanding what we have here called the inherited framework of interdependence, traditional governmental co-operation among states. However, as we have argued, some fundamental objectives after 1945 could not be achieved through such a framework and were therefore advanced through integration.

Yet the Union also reconfigures (or as it is sometimes put, 'hollows out') its member states. For William Wallace (2000, p. 532) therefore, the European states are now 'post-sovereign' given that the EU: 'spills across state boundaries, penetrating deep into previously domestic aspects of national politics and administration".

In ways that approach ideas of multi-level governance (to be reviewed below), Wessels (1997, p. 273) also interprets the EU as an evolution in European sovereignties: 'it is a crucial factor and dynamic engine of the fundamental changes in the statehood of western Europe'.

Chryssochoou's (2001, p. 19) survey describes this and similar accounts of the 'Europeanisation' of EU member states in the following terms:

Arguably, this is a much more complex role than that of merely 'rescuing the nation state' along the lines suggested by Milward [YR] ....This particular interpretation of 'fusion' as a merger process chimes well with the properties of the German system of 'interlocking' federalism or Politikverflechtung.

Others have focused on the way the Union transforms the roles of local governments in member states, in large part by providing a funding agent through which networks and connections are promoted as agents of the internationalization of the $\mathrm{Eu}-$ ropean state (Goldmann, 2001). All these register a more complex political geography than interlocking states and the imagination of a demarcation of inside and outside, which reduces the EU to an expression of a priori bounded entities of territorial states.

\section{Regions, cities, networks and levels}

In characterizing the modes and scales of political power associated with the EU, references to regions have probably been the most durable scale of reference aside from the member states. Political decentralization and attendant constitutional changes in many EU member states have reinforced this. The latter was most marked under socialist governments in the 1980s in the two large hitherto centralized states of France and Spain. However, this coincided with a shift towards greater authority of Länder in West Germany and the project of the EU Commission envisaging a 'Europe of the Regions' as a mode of integration. Thus Michael Keating (1998, p. 16) notes how: 'A new impetus was given to regionalism in Europe during the 1980s and the 1990s by economic restructuring, state reform, globalization and especially by European integration".

However, this has long been (and remains) fluid and uneven (Applegate, 1999). Keating (1998, p. 28) therefore concludes that:

In this context there are some regions which can impose a territorial order and intervene as actors in these complex new systems. In other cases, large cities will take the upper hand. Elsewhere strong states will maintain their power, albeit challenged by new territorial and sectoral power centres. Finally, there are territories which do not have the capacity to impose their own logic and will be forced into dependence on the state or on the international market. Regionalism is a complex phenomenon which cannot be reduced to the notion of a 'level' in the new territorial hierarchy. 
Some confirmation of this may be found in empirical studies of regions that do not have strong coherence or identity. There are many of these across $\mathrm{Eu}-$ rope, places such as the East Midlands (UK), Castilla-La Mancha (Spain), Auvergne (France), Midlands (Irish Republic) and Centro (Portugal) that have relatively little sense of regional distinctiveness. Often these regions came about as part of larger territorial devolutions and reorganizations - either where regions with much stronger identities were granted autonomy (as in Spain, for example), meaning that other segments of the national state territory were granted regional autonomy status too, or as a result of rationalizations and modernist planning schemes for 'functional' regions (as in the 1974 territorial reorganization in the UK, for example). Writing about the trajectory of one of these peripheral UK regions, Gibbs et al. (2001, p. 104) note that:

the Humber Sub-region itself is a particularly 'messy' entity. Rather than a coherent territorial ensemble of production structures, the Sub-region is in practice a disparate mix of industries, towns, cities and rural areas. The present Sub-regional boundaries are relatively recent ones, and not all of the Sub-region has been eligible to receive European funding. However, we suggest that the Humber case has much to say to assertions about governance and institutional capacity - discussions which not only have been based upon limited empirical evidence, but have also tended to focus upon 'successful' or 'transitional' rather than 'less developed' regions, and regions with a dominant metropolitan centre as opposed to areas containing an urban-rural mix.

Their historical and contextual study of this 'region' and reviews of other work on the articulation between local and regional governance in the UK and EU strategies (e.g. Lloyd and Meegan, 1996; MacLeod, 1999; Martin, 1998) leads to the conclusion that:

Existing work has tended to assume a direct link between the regional scale and the development of institutional capacity in particular places. In our view, spatial scale is highly contingent. Particularly in areas characterized by significant political and economic fragmentation, notions of 'the region' cannot be taken as given.

(Gibbs et al., 2001, p. 116)
Other regions, such as the English Southeast and central France, are characterized by weakly developed institutional coherence and formal identity, although few are so large and fragmented as the Southeast (John et al., 2002). The Southeast also bears witness to the ways that: "regions" only exist in relation to particular criteria. They are not "out there" waiting to be discovered; they are our (and others') constructions'. (Allen et al., 1998, p. 2)

In parallel terms, and echoing Duncan and Goodwin (1998), Swyngedouw (2000) points out how regionalizations in Europe - located in response to capitalist restructuring and (broadly neoliberal) political-projects may erode democratic accountability as emergent regional formations and levels are structured and captured by fractions of capital. ${ }^{6}$

In such contexts, Grasse (2001) points again to the heterogeneity of regional level, or what others have termed 'third level' (Bullmann, 1997) structures in the EU. For, on the one hand:

Interregional and cross-border cooperation on the part of subnational authorities is now an established feature of everyday politics, as in the case of the presence of regional lobby groups in Brussels....The establishment of the Committee of the Regions (CoR), the fixing of the subsidiarity principle in the Maastricht Treaty and thus the supposed anchoring of the regions as a definite third level of European politics, as well as Commission policy addressing the regions directly as objects of policy... - all these factors can be taken to indicate an apparently irreversible and uniform trend towards regionalisation in Europe.

(Grasse, 2001,p. 80)

On the other hand:

Regionalization is not a unified theory, which can be put into practice in exactly the same way everywhere, but rather one which remains linked with circumstances and developments, power bases and interest groups of the individual countries concerned.

(Grasse, 2001, pp. 89-90)

\section{Moreover:}

the 'third level' will continue to paint an exceedingly heterogeneous picture. With Eastern enlargement of the EU imminent, and the very different traditions and minority issues this will bring with it, the picture will become yet more complex. (op. cit., p. 92) 
These complexities may to some extent be accommodated in political discourse and practice through a language of 'subsidiarity' and 'flexibility'. Reviewing these, Diez (2001, p. 95) suggests that, while the change registered in the widespread use of these terms (indeed their incorporation into the treaties of the EU and the community laws and practices known as the acquis communautaire), appears relatively marginal: 'these seemingly marginal changes might bring with them more fundamental transformations in that they lay out a linguistic trace that can be seized upon by alternative constructions'.

Thus in recent years an EU sponsored vision of European macro-regions has also added another dimension to the regional level. In the early 1990s, Gripaios and Mangles (1993) drew attention to the European 'super-regions' that were being envisaged by the EU Commission's Directorate-General XVI for Regional Policy and Cohesion (on the longer trajectory and politics of EU regional policy, see Bache, 1998). Since then, the elaboration of what Sparke (2000) terms 'anticipatory geographies' has culminated in the publication of a report on European spatial development (known as Europe 2000+) in 1995 (Albrechts, 1997; Williams, 1996) and the adoption, in 1999, of a European Spatial Development Perspective (ESDP) (Jensen and Richardson, 2001, 2004; Richardson, 2000; Williams, 2000, 2001). Jensen and Richardson (2001, p. 706) thus identify:

The core ESDP vision is centred on a policy triangle of economic and social cohesion, sustainable development and balanced competitiveness, iterated in the final document as: the development of a balanced and polycentric city system and a new urban-rural partnership; securing parity of access to infrastructure and knowledge; and sustainable development, prudent management and protection of nature and cultural heritage.

The ESDP, its forerunners and elaborations, notably the European Spatial Planning Observation Network (ESPON) established in 2002, also articulate what James Scott (2002) has termed a 'strategic cartography' of connection and networks, within what Jensen and Richardson (2004,p.x) call 'a single overarching rationality of making a "one space", made possible by seamless networks enabling frictionless mobility'. In addition, they invoke transnational Euro-regions (see Fig. 1), and

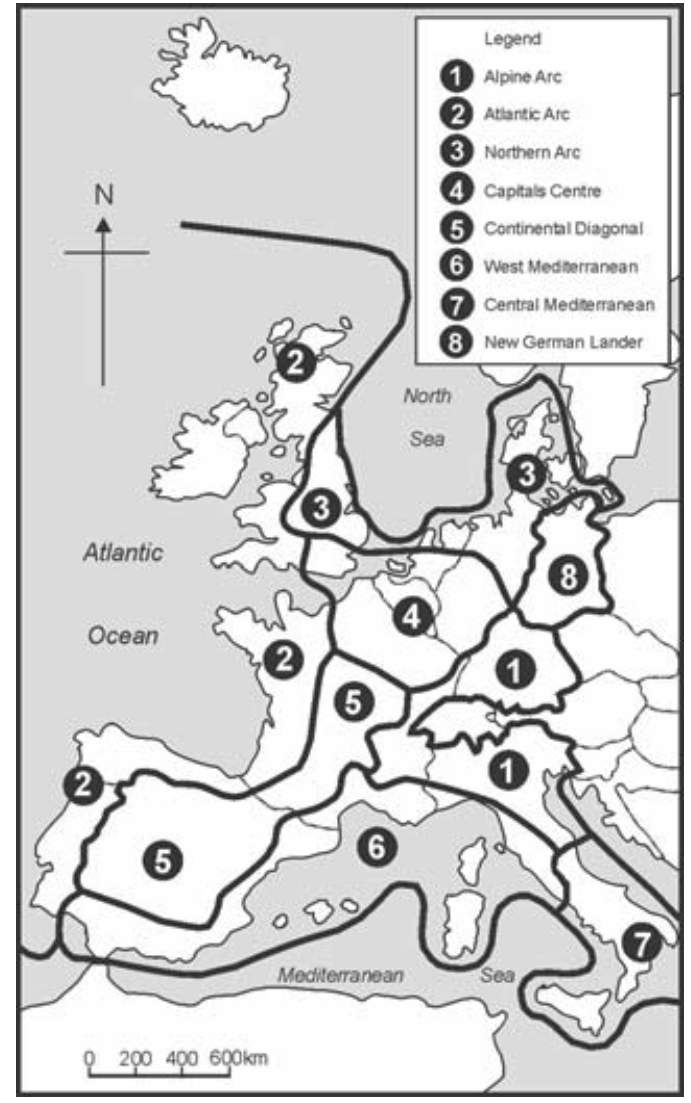

Fig. 1. 'Transnational 'Euro-regions' as proposed in the European Commission's '2000+ Report'.

Source: Redrawn after Wise (2000, p. 867).

what Mark Wise (2000, p. 867) terms 'motivating concepts' for the mobilization of linkages (with a financial raison d'être 'emanating from the centres of politico-economic power'), but with some 'shared competences' (Eser and Konstadakopulos, 2000) across the EU, member states and subnational authorities. As will be detailed below, over the past four years these visions have multiplied, in the forms of reports and maps prepared under the aegis of the ESPON programme.

Regions thus take their place in a burgeoning literature on the EU as a system of 'multi-level governance' (Adshead, 2002). One of the factors underpinning its influence is that this literature operates across a transdisciplinary (and of course, transnational) space of European studies. Its success lies partly in this sociology. As Andrew Jordan (2001, p. 201) notes: 
The term MLG [Multi-level governance] is popular because it captures the mood of the times. By deliberately embracing the discourse of governance it also encourages a healthy dialogue with those studying cognate levels of the EU (such as national political systems), who have traditionally ignored the European dimension. Therefore, in an important sense, MLG successfully carries European studies into other subdisciplines....MLG has also helped pave the way to new research topics such as the governance of the single market...the Europeanisation of member state systems, and the regionalisation of the EU. MLG therefore facilitates synthesis and interaction within European studies, illuminating the interactions between and within different levels.

Such complexities and heterogeneities are embodied in other narratives about the EU. Building on Ruggie (1993), Anderson (1996, pp. 147-149) explores these complexities in historical and comparative perspective - considering Europe as an uneven and partial 'unbundling' of state territoriality:

Rather than focusing on an imagined final outcome, maybe we should focus on process and see European integration in terms of a territorial unbundling which is partial and selective....The overall result of the selectivity or partiality of unbundling is that within Europe there is now a complex mixture of old, new and hybrid forms - 'territorial', 'transterritorial', and 'functional' forms of association and authority coexisting and interacting. For some purposes, territoriality and 'territorial contiguity' are becoming less dominant as modes of social organization and control, and 'nonterritorial' or 'transterritorial' authority is regaining some of the importance it had in medieval times. But for other purposes state sovereignty defined by the same old territorial boundaries seems as firmly rooted as ever.

For other observers (e.g. Caporaso, 1996), the European postmodern polity is not easy to describe. Elements of European politics and governance occupy different sites and intersect. Mamadouh (2001, p. 434) thus notes that the EU has a complex and mobile capital city network, with 'command centres', as she terms them, at such nodes as Brussels, ${ }^{7}$ Strasbourg and Luxembourg, with some EU institutions either 'itinerant' or 'dispersed'. Although there is massive variation among them (see Brenner (1998), for a typology), capital and provincial cities are thereby envisaged as nodes within a fluid European network. This is an active vision in many municipal administrations, in tandem with a variety of "worldcity' discourses (McNeill, 2001). A particular vision of urban networks also crops up in the discourse of the European Commission. Jensen and Richardson (2001, p. 708) thus note how:

the idea of a polycentric urban system...has taken shape through a series of European Commission studies and reports in the 1990 s....The polycentric urban system is seen as a necessary response to environmental, social, and traffic problems of increasing urban growth, by enabling horizontal integration and spreading specialization to a number of urban centres....Strategies for creating a new polycentric European space include the emergence of 'urban networks', including new integration scenarios for cross-border regions in particular....Co-operation between cities across borders may not only imply functional and economic advantages, but may also facilitate the vision of a Europe where national borders are criss-crossed by a new urban policy of inter-city co-operation.

Jensen and Richardson (2001, p. 716) go on to note how this is supplemented with 'infography', such as the figure reproduced here (Fig. 2), used to articulate the concept of polycentricity: 'Infographic framing can be seen as a powerful rhetorical and creative way of reproducing the discourse in new forms of spatial representation'.

While many of the arguments surrounding this concept were developed in the early and mid-twentieth century by Christaller and Lösch, earlier notions of central places and urban networks were predominately visualized with the spaces of the nation-state (Rossler, 1989). Today, European state boundaries are in the background; to be transcended by these webs of interaction (Kramsch and Hooper, 2004; Sidaway, 2001; Walters, 2002). Over the past ten years, this also came to be envisaged as a framework extending eastwards and through which cooperative networks could be established in the context of EU enlargement (Turnock, 2002). Since its establishment in 2002, as a means of informing and fostering the longer established ESDP, the ESPON programme has played a key role in the dissemination of such ways 
of seeing EU spaces, both through ESPON's focus on the territorial implications of enlargement and the way ESPON has combined notions of regions and regional development and networks (especially in the forms of infrastructure and connectivity) through the concept of 'polycentric spatial development'. The ESPON programme incorporates sixteen transnational project groups producing a wealth of maps and reports (see www.espon.lu). The area of study (termed EPSON space) includes the candidate countries for EU membership (minus Turkey), plus two non-member countries which have joined the programme: Switzerland and Norway. Citing ESDP policy, ESPON (2004, p. 10) claims that: "polycentric urban systems are more efficient, more sustainable and more equitable than either monocentric urban systems or dispersed small settlements'.

In turn, it is argued that:

The implementation of a polycentric development model calls for a shift of paradigm away from the centre-periphery thinking in European policies, as well as in national and local policies. Targeted assistance through EU structural policies, the creation of trans-national functional regions, support to specialised networks, and the specialisation of urban areas, as well as institutional setting, transportation and communication links are important elements for achieving a more polycentric Europe.

(ESPON, 2004, p. 10)

Beyond such 'infographics' and their visualizations of (polycentric) networks of cities and urban places, the understanding of Europe, as constituted through networks, is envisaged by Barry (1996, p. 36) as:

a political entity which is expected to be united as much by inhuman bonds as well as by social ties of a more traditional form. The Europe of the network does not claim to possess a centre, or a capital or a common culture: it is a surface of mobile and unstable linkages operating across a space within which national forms of regulation have become increasingly disrupted.

For Barry (1993), therefore, attendant spatial reordering is a key to understanding the mode of governance that the EU seeks to practice. More widely, Jachtenfuchs (2001, p. 253) comments that:

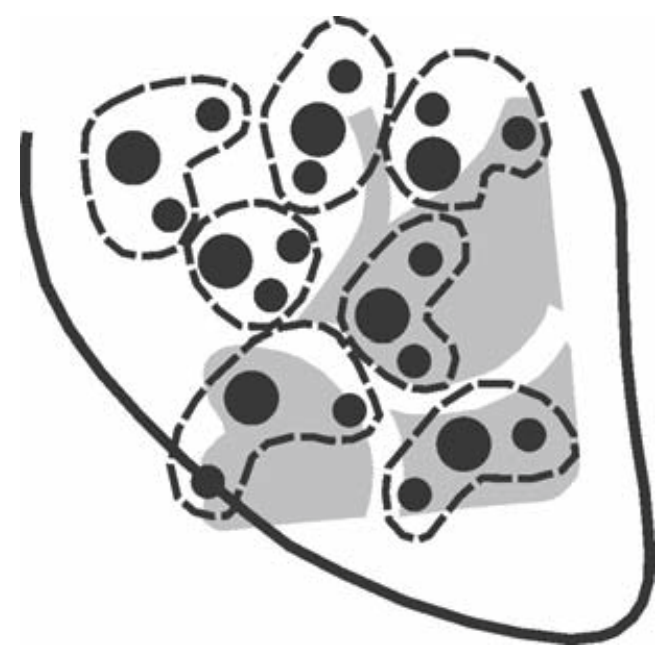

Fig. 2. Polycentricity represented in the ESDP's infographics. Source: Redrawn after Jensen and Richardson (2001, p. 714).

In the policy-analytic literature of the last decade, 'networks' is one of the most frequently used terms. With its emphasis on informal, loose structures that extend across and beyond hierarchies, the network concept appeared particularly well suited to grasp the essence of multi-level governance in the European Union.

What conclusions may be drawn from this array of designations and conceptualizations? Each - so it seems - foregrounds an aspect of the European Union and thereby risks obscuring another. What is at stake in distinguishing between them? What else may be invoked when the political geography of the EU is discussed?

\section{Conclusions: beyond the beast}

Europe seems to be a very complex phenomenon. One might, for example, want to think about Europe in terms of political economies of production or the circulation of capital, or patterns of population movement and immigration, or the place of its largest cities, or the constitution of regions, or its flows of information, or its negotiations of an eastern boundary, or its struggles over specific sites of authority over this, that and the other. That is, one might want to begin not with assumptions about what and where Europe is but with some 
sense of wonder about how it is that all those processes and dynamics that might be identified as relevant to an understanding of Europe can indeed be imagined in terms of a coherent geographical and ontological whole. As with concepts of a state or nation, it is all too easy to assume that Europe simply exists and thus to stop thinking about the conditions under which this assumption comes to be taken for granted or how this assumption is put into practice.

(Walker, 2000, pp. 18-19; italics added)

In the 1970s, Tom Nairn (1977, p. 306) could still condemn the then prevailing attempts to theorize European integration as follows:

All students of the subject soon become aware of one important fact: the monumental sterility, pretension and evasiveness of most theoretical discussion of the European Community. This is the topic on which modern 'political science' has concentrated much of its effort, and done its very worst.

Today things have changed and - as this paper bears witness - a much richer and diverse literature has evolved. Thus, for Jachtenfuchs (whose account of European networks and governance was cited above): 'In the last decade the study of European integration has definitely come through the "dark ages" of the 1970s and early 1980s.' (2001, pp. 245-246).

However, as has also been stressed here, there is little consensus about what the EU represents. Therefore, amidst the diversity of positions and views rehearsed in this paper, a way forward is to rephrase the question of what is the spatiality (or more narrowly, perhaps, the political geography) of EU governance towards critical scrutiny of how this is discursively constructed. Therefore, there is no single, stable, hegemonic understanding of the EU. Instead, a variety of visions exist in circulation and contest, embodying (though rarely in a straightforward or direct way) different social interests. The recent expansion of accounts of the social construction of Europe (see Christiansen et al., (2001) for a survey) has made this more explicit. Therefore, as Diez (2001, pp. 91-92) notes:

any 'description' of European governance participates in the struggle to fix the latter's meaning, and is thus a political act....The power of discourse is that it structures our conceptualizations of European governance to some extent, rather than simply employing a certain language to further our cause. The multi-level language gives preference to actors on various 'state' levels.... What happens if for a moment we employ a different language and speak of a 'network polity' instead? Our conception of the EU changes, and instead of 'levels', we find a more open political space, both geographically and functionally diversified, undermining the territorial notion of politics that is still upheld by the multiple levels concept.

Thus, the European Union has no straightforward sum and substance. It is rendered meaningful and real through complex systems of representation. Indeed, that it has no eternal essence is borne out in the open contest between different representations. Viewed through such an approach, it is not simply the case that EU member states are retaining 'power' or fading in their relative importance, nor is it sufficient to detect new levels or networks of governance. Neither the state, nor the Union, the region or third level or the network are ontological fundamentals or intrinsic truths. This is not to deny that these are useful categories of analysis, nor to assert that they are intangible or meaningless. Indeed, these categorizations and abstractions have formed domains of analysis and meaning here. But that reality may usefully be understood not as 'given' in the categories, but as unfolding or rendered in complex and contested movements of discourse. In terms therefore of different visions and theorizations of the EU, not only are these productive of what they purport to describe, but they thereby invite and invoke different actions and spaces of possibility for different subjects. Hence a key task of critical work is the specification of how different scaled visions are produced, circulate, and with what consequences.

\section{Acknowledgements}

An earlier version of this paper was presented as a plenary paper at the 22nd Conference of the New Zealand Geographical Society - hosted by the School of Geography and Environmental Science at the University of Auckland in July 2003. It was subsequently presented in the same month at the National Centre for Research on Europe at the University of Canterbury, Christchurch, New Zealand. In both places, I am grateful to the organizers and to the 
audiences for critical suggestions. In addition, comments and suggestions from Olivier Kramsch, Prem Kumar Rajaram, Robina Mohammad, Michael Samers, Adrian Smith, Henry Yeung and the anonymous referees are gratefully acknowledged. Peter Shirlow helpfully pointed me to some literatures by and on fundamentalist Protestant interpretations of the EU. Responsibility for errors, limitations and misinterpretations remains mine.

\section{Notes}

1 This paper mostly leaves aside the geographies of socioeconomic disparity (versus convergence) in the EU. Suffice to note briefly here that a series of empirical studies by geographers point to a mixed pattern. Thus, in the early 1990s, anticipating the much-vaunted arrival of the 'Single European Market', Amin et al. (1992, p. 330) judged that: In the context of increased concentration and globalization of corporate activity, the focus of EC regional policy on developing indigenous potential...is an insufficient corrective against the centralization of corporate power and control in the core regions of Europe.

More recently, Dunford and Smith (2000, pp. 170, 193194) conclude that the 'map of economic inequality in contemporary Europe' shows a 'divide of quite significant and enduring proportions' and 'that differentiation is more apparent than convergence'. Agnew (2001) reflects on what this signifies for an enlarging EU in a Europe of socio-spatial disparity and proliferating uneven development. Similarly, Jones and MacLeod (1999, p. 308) note that in Britain and Europe: 'beneath (or perhaps above) all the celebratory discourses...hovers a capricious scenario of combined and uneven development, intense interterritorial competition, devaluation and overaccumulation'.

2 On cultural geographies of EU governance and policy, see Barnett (2001). Shore (2000) provides an original anthropology of the EU Commission.

3. On European cities, scale, governance and European integration, see Le Galès (2002). Brenner (2004) provides a review of changing modes of urban governance in the contexts of Europeanization understood as a complex rescaling.

4. The range of approaches being brought to bear on the analysis of European integration continues to broaden, with, for example, recent feminist (Hansen, 2000) and postcolonial (Böröcz, 2001; Kramsch, 2002; Kuus, 2004) work. In recent years, the journal Geopolitics has published a series of papers and special issues exploring 'The changing geopolitics of Eastern Europe' (6 summer 2001), 'The critical geopolitics of Northern Europe' (8 Spring 2003) and 'Postnational politics in the European Union' (9 Autumn 2004).

5. On the ways that Russia (and other places associated with 'Easterness') form the basis of constructions of self-other in Western European narratives, see Neumann (1999).

6. In the UK context too, subsequent work drawing upon regulationist perspectives has explored shifting technologies and rearticulations of governance, in the context of uneven power and influence and class-regional reconfigurations. The literature on the UK is too extensive and the theme too far from my core focus in this article to review extensively here; however examples are Edwards, et al., (2001), Gibbs and Jonas (2001), Goodwin and Painter (1996), Jones and MacLeod (2004), MacKinnon (2000), MacLeod (1998),
MacLeod and Goodwin (1999), Peck and Tickell (1995). What emerges in these, and is foregrounded in Imrie and Raco (1999, p. 59), is the difficulty of conceiving 'of a generic form of local [or regional] governance - rather, there is a hybrid of possible (and potential) forms, incorporating a range of institutional networks and modes of policy development and implementation'. Giordano's (2001) account of Northern League regionalism in Italy also points to similar contingencies.

7. See Baeten (2001) on the 'Europeanization' of Brussels itself.

\section{James D Sidaway \\ Department of Geography \\ National University of Singapore \\ Singapore 117570}

Current address:

Department of Geography

Loughborough University

Loughborough

Leicestershire LE11 3TU

United Kingdom

E-mail: j.d.sidaway@lboro.ac.uk

\section{References}

ADSHEAD, M. (2002): Developing European Regions? Comparative Governance, Policy Networks and European Integration. Ashgate, Aldershot.

AGNEW, J. (2001): 'How many Europes? The European Union, eastward enlargement and uneven development', European Urban and Regional Studies, 8: 29-38.

ALBRECHTS,L.(1997): 'Genesis of a Western European spatial policy', Journal of Planning Education and Research, 17: $158-167$.

ALLEN, J., MASSEY, D., COCHRANE, A. et al. (1998): Rethinking the Region. Routledge, London and New York.

AMIN, A., CHARLES, D.R. and HOWELLS, J. (1992): 'Corporate restructuring and cohesion in the new Europe', Regional Studies, 26: 319-331.

ANDERSON, J. (1996): 'The shifting stage of politics: new medieval and postmodern territorialities', Environment and Planning D: Society and Space, 14: 133-153.

APPLEGATE, C. (1999): 'A Europe of the regions: reflections on the historiography of sub-national places in modern times', American Historical Review, 104: 1157-1182.

BACHE, I. (1998): The Politics of European Union Regional Policy: Multi-level Governance or Flexible Gatekeeping? Sheffield Academic Press, Sheffield.

BAETEN, G. (2001): 'The Europeanisation of Brussels and the urbanization of Europe: hybridizing the city, empowerment and disempowerment in the EU district', European Urban and Regional Studies, 8: 117-130.

BARNETT, C. (2001): 'Culture, policy and subsidiarity in the European Union: from symbolic identity to the governmentalisation of culture', Political Geography, 20: 405-426.

BARRY, A. (1993): 'The European network', New Formations, 29: 26-37.

BARRY, A. (1996): 'The European Community and European government: harmonization, mobility and space', Economy and Society, 22: 314-326. 
BLACKSELL, M. (1977): Post-war Europe: A Political Geography. Dawson, Folkstone.

BOERI, S. (2001): 'Notes for a research program', in KOOLHAAS, R., BOERI, S., KWINTER, S., TAZI, N. and OBRIST, H.U. (eds): Mutations, ACTAR and arc en rêve centre d'architecture, Barcelona and Bordeaux.

BöRöCZ, J. (2001): 'Empire and coloniality in the 'Eastern Enlargement' of the European Union', in BöRöCZ, J. and KOVÁS, M. (eds): Empires' New Clothes: Unveiling EU Enlargement. Central European Review, Telford.

BORNSCHIER V. (2001): 'European processes and the state of the European Union', in WOODWARD. A. and KOHLI, M. (eds): Inclusions and Exclusions in European Societies. Routledge, London and New York.

BOWER, P. (1992): When Time Shall Be No More: Prophecy Belief in Modern American Culture. Harvard University Press, Cambridge MA.

BRENNER, N. (1998): 'Global cities, glocal states: global city formation and state territorial restructuring in contemporary Europe', Review of International Political Economy, 5: 1-37.

BRENNER, N. (2004): 'Urban governance and the production of new state spaces in western Europe, 1960-2000', Review of International Political Economy, 11: 447-488.

BULLMANN, U. (1997): 'The politics of the Third Level', Regional and Federal Studies, 6: 3-19.

CAPORASO, J.A. (1996): 'The European Union and forms of state: Westphalian, regulatory or post-modern?' Journal of Common Market Studies, 34: 29-51.

CHRISTIANSEN, T., JøRGENSEN, K.E. and WIENER, A. (eds) (2001): The Social Construction of Europe. Sage, London, Thousand Oaks and New Delhi.

CHRYSSOCHOOU, D.N.(2001): Theorizing European Integration. Sage, London, Thousand Oaks and New Delhi.

CHURCH, C.H. and PHINNEMORE, D. (2002): The Penguin Guide to the European Treaties. Penguin, London.

CLARK, G. (2001): 'Vocabulary of the new Europe: code words for the millennium', Environment and Planning D: Society and Space, 19: 697-717.

DIEZ, T. (2001): 'Speaking "Europe": the politics of integration discourses', in CHRISTIANSEN, T., JøRGENSEN K.E. and WIENER, A. (eds): The Social Construction of Europe. Sage, London, Thousand Oaks and New Delhi.

DUNCAN S. and GOODWIN, M. (1988): The Local State and Uneven Development: Behind the Local Government Crisis. Cambridge, Polity Press.

DUNFORD, M. and SMITH, A. (2000): 'Catching up or falling behind? Economic performance and regional trajectories in the "New Europe", Economic Geography, 76: 169-195.

ECONOMIST, THE (2005): 'Charlemagne: taking on the bear, The Economist, 7-13 May: 48.

EDWARDS, B., GOODWIN, M., PEMBERTON, S. and WOODS M. (2001): 'Partnerships, power, and scale in rural governance', Environment and Planning C: Government and Policy, 19: 289-310.

ELLIS, S. and TER HAAR, G. (1998): 'Religion and politics in Sub-Saharan Africa', The Journal of Modern African Studies, 36: 175-201.

ESER, T.W. and KONSTADAKOPULOS, D. (2000): 'Power shifts in the European Union? The case of spatial planning', European Planning Studies, 8: 783-798.

ESPON (2004): ESPON in Progress: Preliminary Results by Autumn 2003. The ESPON Programme, Luxembourg.

GIBBS, D. and JONAS, A.E.G. (2001): 'Rescaling and regional governance: the English Regional Development Agencies and the environment', Environment and Planning C: Government and Policy, 19: 269-288.
GIBBS, D., JONAS, A.E.G., REIMER, S. and SPOONER, D.J. (2001): 'Governance, institutional capacity and partnerships in local economic development: theoretical issues and empirical evidence from the Humber sub-region', Transactions of the Institute of British Geographers NS, 26: 103119.

GIORDANO, B. (2001): “"Institutional thickness”, political subculture and the resurgence of (the "new") regionalism in Italy - a case study of the Northern League in the province of Varese', Transactions of the Institute of British Geographers NS, 26: $25-41$.

GOLDMANN, K. (2001): Transforming the European Nationstate. Sage, London, Thousand Oaks and New Delhi.

GOODWIN, M. and PAINTER, J. (1996): 'Local governance, the crises of fordism and the changing geographies of regulation', Transactions of the Institute of British Geographers, 21: 635648.

GRAHAM, B. (1998): Modern Europe: Place, Culture. Identity. Arnold, London.

GRASSE, A. (2001): 'The myth of regionalisation in Europe rhetoric and reality of an ambivalent concept', Journal of European Area Studies, 9: 79-82.

GRIPAIOS, P. and MANGLES, T. (1993): 'An analysis of European super regions', Regional Studies 27: 745-750.

HANSEN, L. (2000): 'Gendered communities: the ambiguous attraction of Europe', in KELSTRUP, M. and WILLIAMS, M.C. (eds): International Relations Theory and the Politics of European Integration: Power, Security and Community. Routledge, London and New York.

HEFFERNAN, M. (1998): 'Fin de siècle, fin du monde? On the origins of European geopolitics, 1890-1920', in DODDS, K. and ATKINSON, D. (eds): Geopolitical Traditions: A Century of Geopolitical Thought, Routledge, London and New York.

HELLSTRÖM, A. (2003): 'Beyond space: border making in European integration, the case of Ireland', Geografiska Annaler Series B, 85: 123-135.

HERMAN, D. (2000): 'The New Roman Empire: European envisionings and American premillennialists', Journal of American Studies, 34: 23-40.

HOFFMANN, S. (1966): 'Obstinate and obsolete? The fate of the nation state in the case of Western Europe', Daedalus, 95: $862-915$.

HUDSON, R. and WILLIAMS, A.M. (eds) (1999): Divided Europe: Society and Territory. Sage, London, Thousand Oaks and New Delhi.

IMRIE, R. and RACO, M. (1999): 'How new is the new local governance? Lessons from the United Kingdom', Transactions of the Institute of British Geographers NS, 24: 45-63.

JACHTENFUCHS, M. (2001): 'The governance approach to European integration', The Journal of Common Market Studies, 39: $245-264$.

JENSEN, O.B. and RICHARDSON, T. (2001): 'Nested visions: new rationalities of space in European Spatial Planning', Regional Studies, 35: 703-717.

JENSEN, O.B. and RICHARDSON, T. (2004): Making European Space: Mobility, Power and Territorial Identity. Routledge: London and New York.

JOHN, P., MUSSON, S. and TICKELL, A. (2002) 'England's problem region: regionalism in the South-East', Regional Studies, 36: 733-741.

JONES, M. and MACLEOD, G. (1999): 'Towards a regional renaissance? Reconfiguring and rescaling England's economic governance', Transactions of the Institute of British Geographers NS, 24: 295-313.

JONES, M. and MACLEOD, G. (2004) 'Regional spaces, spaces 
of regionalism: territory, insurgent politics and the English question', Transactions of the Institute of British Geographers NS, 29: 433-452.

JöNSSON, C., TÄGIL, S. and TöRNQVIST, G. (2000): Organizing European Space. Sage, London, Thousand Oaks and New Delhi.

JORDAN, A. (2001): 'The European Union: an evolving system of multi-level governance....or government?', Policy and Politics, 29: 193-208.

KEATING, M. (1998): 'A regional level of government in Europe?', in LE GALÈS, P. and LEQUESNE, C. (eds): Regions in Europe. Routledge, London and New York.

KRAMSCH, O. (2002): 'Re-imagining the scalar topologies of cross-border governance: Eu(ro)regions in the postcolonial present', Space and Polity, 6: 169-196.

KRAMSCH, O. and HOOPER, B. (eds) (2004): Cross-border Governance in the European Union. Routledge, Abingdon and New York.

KUUS, M. (2004): 'Europe's eastern expansion and the reinscription of otherness in East-Central Europe', Progress in Human Geography, 28: 472-489.

LEE, R. and OGDEN, P. (1976): Economy and Society in the EEC: Spatial Perspectives. Saxon House, Farnborough.

LE GALÈS, P. (2002): European Cities: Social Conflicts and Governance. Oxford University Press, New York and Oxford.

LLOYD, P. and MEEGAN, R. (1996): 'Contested governance: European experience in the English regions', European Planning Studies, 4: 75-97.

MACKINNON, D. (2000): 'Regulating regional spaces: state agencies and the production of governance in the Scottish Highlands', Environment and Planning A, 33: 823-844.

MACLEOD, G. (1998): 'In what sense a region? Place, hybridity, symbolic shape and institutional formation in (post) modern Scotland', Political Geography, 17: 833-863.

MACLEOD, G. (1999): 'Place, politics and "scale dependence"': exploring the strucuration of Euro-regionalism', European Urban and Regional Studies, 6: 231-253.

MACLEOD, G. and GOODWIN, M. (1999): 'Space, scale and state strategy: rethinking urban and regional governance', Progress in Human Geography, 23: 503-527.

MAMADOUH, V. (2001): 'The territoriality of European integration and the territorial features of the European Union: the first 50 years', Tijdschrift voor Economimische en Sociale Geografie, 92: 420-436.

MARTIN, S. (1998): 'EU programmes and the evolution of local economic governance in the UK', European Urban and Regional Studies, 5: 237-248.

MCNEILL, D. (2001): 'Embodying Europe of the cities: geographies of mayoral leadership', Area, 35: 353-359.

MCNEILL, D. (2004): New Europe: Imagined Spaces. Arnold, London.

MILWARD, A.S. (1992): The European Rescue of the Nation State. Routledge, London and New York.

MILWARD, A.S. (1993): 'Conclusions: the value of history', in MILWARD, A.S., LYNCH, F.M.B., ROMERO, F., RANIERI, R. and SøRENSEN, V. (eds): The Frontier of National Sovereignty: History and Theory 1945-1992. Routledge, London and New York.

MILWARD, A.S. and SØRENSEN, V. (1993): 'Independence or integration? A rational choice', in MILWARD, A.S., LYNCH, F.M.B., ROMERO, F., RANIERI, R. and SøRENSEN, V. (eds): The Frontier of National Sovereignty: History and Theory 1945-1992. Routledge, London and New York.

MILWARD, A.S., LYNCH, F.M.B., ROMERO, F., RANIERI, R. and SØRENSEN, V. (eds) (1993): The Frontier of Nation- al Sovereignty: History and Theory 1945-1992, Routledge, London and New York.

MITCHELL, T. (1998): Betrayal of the Innocents: Desire, Power and the Catholic Church in Spain. University of Pennsylvania Press, Philadelphia.

MOISIO, S. (2002): 'EU eligibility, Central Europe, and the invention of applicant state narrative', Geopolitics, 7: 89-116.

MORAVCSIK, A. (1991): 'Negotiating the Single European Act: national interests and conventional statecraft in the European Community', International Organisation, 45:1.

MORAVCSIK, A. (1993): 'Preferences and power in the European Community: a liberal intergovernmentalist approach', Journal of Common Market Studies, 31: 473-524.

MORAVCSIK, A. (1998): The Choice for Europe: Social Purpose and State Power from Messina to Maastricht. Cornell University Press, Ithaca, NY.

NAIRN, T. (1977): The Break-up of Britain: Crises and Neonationalism. New Left Books, London.

NEUMANN, I.B. (1999) Uses of the Other: 'The East' in European Identity Formation. Manchester University Press, Manchester.

NICOLAÏDIS, K. and HOWSE, R. (2002): “"This is my EUtopia...": narrative as power', Journal of Common Market Studies, 40: 767-792.

NOBLE, A. (1998): 'The conspiracy behind the European Union: what every Christian should know'. Lecture delivered at the Annual Autumn Conference of the United Protestant Council in London on 7 November (http://www.ianpaisley.org/article.asp? ArtKey=conspiracy, accessed 4 August 2000).

NUGENT, N. and PATERSON, W. (2003): 'The political system of the European Union', in HAYWARD, J. and MENON, A. (eds): Governing Europe. Oxford University Press, New York and Oxford.

OLSEN, J.P. (2002): 'The many faces of Europeanization', Journal of Common Market Studies, 40: 921-952.

PAASI, A. (2001): 'Europe as a social process and discourse: considerations of place, boundaries and identity', European Urban and Regional Studies, 8: 7-28.

PARKER, G (1983): A Political Geography of Community Europe. Butterworths, London.

PECK, J. and TICKELL, A. (1995): 'The social regulation of uneven development: 'regulatory deficit', England's South East and the collapse of Thatcherism', Environment and Planning A, 27: $15-40$.

PUCHALA, D.J. (1972): 'Of blind men, elephants and European Integration', Journal of Common Market Studies, 10: 267-284.

RICHARDSON, T. (2000): 'Discourses of rurality in EU spatial policy: the European Spatial Development Perspective', Sociologia Ruralis, 40: 53-71.

ROSAMOND, B. (2000): Theories of European Integration. Macmillan, Basingstoke.

ROSSLER, M. (1989): ‘Applied geography and area research in Nazi society: central place theory and planning', Environment and Planning D: Society and Space, 7: 419-431.

RUGGIE, J. (1993): 'Territoriality and beyond: problematising modernity in international relations', International Organisation, 47: 139-174.

SASSOON,D. (1997): One Hundred Years of Socialism: the West European Left in the Twentieth Century. Fontana Press, London.

SCOTT, J.W. (2002): 'A networked space of meaning? Spatial politics as geostrategies of European integration', Space and Polity, 6: 147-167.

SHIRLOW, P. (2000): 'Fundamentalist loyalism: discourse, resistance and identity politics ', in GOLD, J. and REVILL, G. (eds): Landscapes of Defence. Prentice Hall, London. 
SHORE, C. (1997): 'Metaphors of Europe: integration and the politics of language', in NUGENT, S. and SHORE, C. (eds): Anthropology and Cultural Studies. Pluto, London.

SHORE, C. (2000): Building Europe: the Cultural Politics of European Integration. Routledge, London and New York.

SIDAWAY, J.D. (2001): 'Rebuilding bridges: a critical geopolitics of Iberian transfrontier cooperation in a European context', Environment and Planning D: Society and Space, 19: 743-778.

SMITH, A. (2002): 'Imagining geographies of the "new Europe": geo-economic power and the new European architecture of integration', Political Geography, 21: 647-670.

SPARKE, M. (2000): “Chunnel Visions": unpacking the anticipatory geographies of an Anglo-European borderland', Journal of Borderlands Studies, 25: 187-219.

SWYNGEDOUW E. (2000): 'Authoritarian governance, power, and the politics of rescaling', Environment and Planning D: Society and Space, 18: 63-76.

TURNOCK, D. (2002): 'Cross-border cooperation: a major element in regional policy in East Central Europe', Scottish Geographical Journal, 118: 19-40.

WALKER, R.B.J. (2000): 'Europe is not where it is supposed to be', in KELSTRUP, M. and WILLIAMS, M.C. (eds): International Relations Theory and the Politics of European Inte- gration: Power, Security and Community. Routledge, London and New York.

WALLACE, H. (2000): 'Analysing and explaining policies', in WALLACE, H. and WALLACE, W. (eds): Policy-making in the European Union. (4th edn) Oxford University Press, Oxford.

WALLACE, W. (2000): 'Collective governance', in WALLACE, H. and WALLACE, W. (eds): Policy-making in the European Union, fourth edition, Oxford University Press, Oxford.

WALTERS, W. (2002): 'Mapping Schengenland: denaturalizing the border', Environment and Planning D: Society and Space, 20: $561-580$.

WESSELS, S. (1997): 'An ever closer fusion? A dynamic macropolitical view on integration processes', Journal of Common Market Studies, 35: 2.

WILLIAMS, R.H.(2000): 'Constructing the European Spatial Development Perspective - for whom?', European Planning Studies, 8: 357-365.

WILLIAMS, R.H. (2001): 'The contribution of spatial planning to social cohesion in the European Union', in HALLER, M. (ed): The Making of the EU. Springer, Berlin.

WISE, M. (2000): 'The Atlantic Arc: transnational European reality or regional mirage?', Journal of Common Market Studies, 38: $865-890$. 